\title{
Evaluation of acibenzolar-S-methyl for the control of Meloidogyne javanica and effects on the development of susceptible and resistant soybean
}

\author{
Heriksen H. Puerari ${ }^{1}$, Claudia R. Dias-Arieira ${ }^{1}$, Tais S. Dadazio ${ }^{2}$, Danielle Mattei ${ }^{2}$, Tiago R.B. da Silva ${ }^{2}$ \& \\ Regina C.F. Ribeiro ${ }^{3}$
}

${ }^{1}$ Universidade Estadual de Maringá (UEM), 87020-900, Maringá, PR, Brazil; ²UEM, Campus Umuarama, 87501-970, Umuarama, PR, Brazil; ${ }^{3}$ Universidade Estadual de Montes Claros, 39440-000, Janaúba, MG, Brazil

Author for correspondence: Claudia R. Dias-Arieira, e-mail: crdarieira@uem.br

\begin{abstract}
The aim of this study was to evaluate the activity of elicitor, acibenzolar-S-methyl (ASM), in inducing resistance to Meloidogyne javanica in soybean and in enhancing plant development. Plantlets of the soybean susceptible cultivar BRSMT-Pintado and the resistant cultivar MG/BR 46 Conquista were treated with ASM $(0.5 \mathrm{~g} / \mathrm{L})$ at three different times: seven days before, one day before and seven days after inoculation with 2000 eggs/plant. Untreated inoculated plants and untreated non-inoculated plants were used as controls. Sixty days after inoculation, the number of galls, eggs/g root and vegetative parameters (height, aerial part fresh and dry mass and root fresh mass) were evaluated. The experiments were conducted over two different periods (Experiments 1 and 2). Only in Experiment 2 treatment "seven days before inoculation" reduced the number of eggs/g root, irrespective of the cultivar evaluated, but the number of galls was not affected. Stronger plant development was observed in the susceptible soybean cultivar treated seven days before inoculation in Experiment 2.

Key words: induced resistance, inducers, management, phytonematodes, root-knot nematode.
\end{abstract}

Induced resistance has recently been the topic of many studies, as an environmentally-friendly approach to control plant diseases. Induced resistance has achieved some promising results, proving efficient in the management of various pathosystems. However, studies have been concentrated mainly on the control of fungal and bacterial diseases (Benhamou \& Belanger, 1998; Baysal et al., 2003; Vallad \& Goodman, 2004; Bonaldo et al., 2005).

Induced resistance is defined as an increase in the plant capacity to defend itself against pathogens, acquired after the activation of resistance mechanisms by various agents (Benhamou \& Belanger, 1998), and involving specific sets of genes, including those that code for pathogenesisrelated proteins and enzymes (Durrant \& Dong, 2004).

Elicitors or inducers can be chemical substances, plant extracts or live microrganisms (Benhamou \& Belanger, 1998; Fabry et al., 2007; Franzener et al., 2007; Dias-Arieira et al., 2012). Synthetic elicitors have the advantage of avoiding direct antimicrobial activity, in contrast to traditional products, reducing the selection pressure on pathogen populations. Furthermore, they are reputed to be safer for the environment than currently-used pesticides (Vallad \& Goodman, 2004). However, they often fail to provide complete and lasting control of infection (Walters et al., 2005).

Chemicals used to activate resistance mechanisms include phosphites, salicylic acid (SA), acetylsalicylic acid, methyl jasmonate and acibenzolar-S-methyl (ASM)
(Oostendorp et al., 2001; Walters et al., 2005; Salgado et al., 2007; Dias-Arieira et al., 2012). ASM is one of the most widely researched chemical inducers and is used mainly for inducing plant resistance to fungal, bacterial and viral diseases (Steiner \& Schönbeck, 1995; Vallad \& Goodman, 2004; Walters et al., 2005).

Studies on induced resistance to nematodes have tended to appear more frequently over the last few years, investigating elicitors and a range of phytonematodes that attack various crops (Silva et al., 2004; Fabry et al., 2007; Franzener et al., 2007; Salgado et al., 2007; Dias-Arieira et al., 2012). In studies on induced resistance, there are no restrictions, regarding annual or perennial crops, but some factors must be taken into consideration, including the nature of the interaction of the specific pathosystem, the genetics of the host plant, and the need to boost defense mechanisms if the inducing agent has only a temporary effect (Salgado et al., 2007).

Despite the number of studies already conducted on resistance inducers, many pathosystems involving nematodes have not yet been studied, and there are still gaps in the research concerning differentiated responses to inducers exhibited by resistant plants. Therefore, the aim of this study was to evaluate the effects of ASM treatment at different periods on the population of Meloidogyne javanica (Treub) Chitwood in two soybean [Glycine max (L.) Merrill] cultivars. 
The experiments were conducted in the greenhouse at the Universidade Estadual de Maringá, Umuarama Regional Campus, using a fully randomized design with six replications. They were carried out during two different periods: from October, 23 $3^{\text {th }} 2011$ to January, 23 2012 (Experiment 1) and from December, $5^{\text {th. }} 2011$ to March, $5^{\text {th. }}$ 2012 (Experiment 2).

Soybean plantlets were produced on polystyrene trays containing a Plantmax ${ }^{\circledR}$ substrate. When the first pair of trifoliates had fully expanded, the plantlets were transplanted to $1.5 \mathrm{~L}$ pots containing a soil/sand mix (2:1, v:v), previously autoclaved for 2 hours at $120^{\circ} \mathrm{C}$. Two soybean cultivars were studied: BRSMT-Pintado, considered susceptible to the nematode, and MG/BR 46 Conquista, considered resistant (Silva, 2001).

The inducer used was ASM at the dose recommended by the manufacturer $(0.5 \mathrm{~g} / \mathrm{L})$. ASM was applied at three different stages: seven days before nematode inoculation, one day before nematode inoculation and seven days after nematode inoculation. Untreated inoculated plants were used as controls for comparing nematological parameters. An additional control was included (untreated, noninoculated plants) so that vegetative parameters could be compared. ASM was applied by spraying the aerial part until surface runoff, protecting the soil so that none of the treatment dripped onto it.

The inoculum was obtained from a pure population of M. javanica kept in the roots of tomato plants. The method proposed by Hussey \& Barker (1973) was used to extract the eggs from the roots. The suspension was calibrated to 500 eggs and any second-stage juveniles (J2) per milliliter. Each pot was inoculated with $4 \mathrm{~mL}$ of the suspension, dripped into four equidistant holes approximately $4 \mathrm{~cm}$ deep in the soil around the plant, to provide an inoculated population of 2000 eggs and $\mathbf{J} 2 /$ plant.
The plants were kept in the greenhouse for 60 days and watered daily. After this period, they were collected and the aerial parts separated from the root systems. The height of the aerial part was measured using a millimeter rule, and fresh and dry mass determined on a semi-analytical balance. Aerial part dry mass was determined by placing the aerial parts in paper bags and keeping them in drying hothouse with air circulation at $65^{\circ} \mathrm{C}$ until a constant mass was reached. Root systems were carefully washed and placed on absorbent paper to remove excess water. Root fresh mass was determined, the number of galls counted, and the number of eggs/root system determined using the extraction system mentioned above. The number of eggs was evaluated using Peters slide under an optical microscope. The total number of eggs/root system was divided by the mass of the roots to determine the number of eggs/g root. The data obtained on each cultivar were subjected to analysis of variance and the means compared using the Tukey test at $5 \%$ of probability.

For the susceptible soybean cultivar (BRSMTPintado), we observed that treatment with ASM was not effective in reducing the number of galls, since in both experiments the number of galls for all treatments was the same or higher than of the control, irrespective of the time of application (Table 1). In regard to the number of nematodes, in Experiment 1 there was no statistical difference among the treatments, but in Experiment 2, the number of nematodes was significantly lower in plants treated seven days before inoculation than in the untreated inoculated control.

As observed for the BRSMT-Pintado cultivar, the number of galls showed no significant difference for the MG/BR 46 Conquista cultivar, irrespective of the treatment time (Table 1). However, when compared to the control, the number of eggs was significantly lower for the treatment one day before inoculation in Experiment 1, and seven days before or after inoculation in Experiment 2. In general,

TABLE 1 - Number of galls and eggs/g root in two soybean cultivars treated with acibenzolar-S-methyl seven days and one day before and seven days after inoculation with 2000 eggs of Meloidogyne javanica in experiments conducted during two different periods

\begin{tabular}{|c|c|c|c|c|}
\hline \multirow[t]{2}{*}{ Treatment } & \multicolumn{2}{|c|}{ Experiment 1} & \multicolumn{2}{|c|}{ Experiment 2} \\
\hline & Galls & Eggs/g root & Galls & Eggs/g root \\
\hline \multicolumn{5}{|c|}{ BRSMT-Pintado (susceptible) } \\
\hline 7 days before & $119.4 \mathrm{c}$ & $1564.5^{\mathrm{ns}}$ & $51.2 \mathrm{a}$ & $2054.3 \mathrm{a}$ \\
\hline 1 day before & $87.2 \mathrm{~b}$ & 1018.1 & $129.8 \mathrm{~b}$ & $5075.2 \mathrm{c}$ \\
\hline 7 days after & $80.0 \mathrm{~b}$ & 1250.6 & $37.0 \mathrm{a}$ & $4520.7 \mathrm{bc}$ \\
\hline Control & $53.0 \mathrm{a}$ & 1390.9 & $35.8 \mathrm{a}$ & $3189.7 \mathrm{~b}$ \\
\hline CV $(\%)$ & 47.2 & 31.8 & 31.8 & 48.1 \\
\hline \multicolumn{5}{|c|}{ MG/BR 46 Conquista (resistant) } \\
\hline 7 days before & $24.0^{\mathrm{ns}}$ & $411.1 \mathrm{ab}$ & $31.0^{\mathrm{ns}}$ & $702.5 \mathrm{a}$ \\
\hline 1 day before & 20.4 & $250.4 \mathrm{a}$ & 48.0 & $1420.9 \mathrm{~b}$ \\
\hline 7 days after & 15.3 & $813.8 \mathrm{~b}$ & 44.0 & $664.1 \mathrm{a}$ \\
\hline Control & 17.6 & $711.0 \mathrm{~b}$ & 34.6 & $1111.8 \mathrm{~b}$ \\
\hline $\mathrm{CV}(\%)$ & 32.3 & 28.2 & 31.9 & 27.9 \\
\hline
\end{tabular}

For each cultivar, means in columns followed by the same letter did not differ in the Tukey test at $5 \%$ of probability. ${ }^{\text {ns }}=$ not significant. Control $=$ untreated/inoculated plants. 
the results for the two experiments were not consistent, in Experiment 1, application of ASM one day before inoculation was the treatment that produced the lowest number of eggs, even lower than ASM treatment seven days before nematode inoculation, although differences were not significant.

In regard to the vegetative development of the susceptible soybean (Table 2), only in Experiment 2 there was any difference between the treatments. The plant height, aerial part fresh and dry mass and root fresh mass were significantly higher for plants treated seven days before inoculation when compared to untreated/inoculated plants, and the values were statistically the same as those for the untreated/non-inoculated plants. The results for treatment one day before or seven days after inoculation did not differ statistically from the untreated/non-inoculated control, except for height and aerial part fresh mass.

For the resistant soybean cultivar, in Experiment 1 the plants treated one day before and seven days after inoculation shower lower height than the inoculated controls. Besides, the aerial part fresh and dry mass and root fresh mass parameters were significantly lower in the treatment seven days after inoculation. In Experiment 2, aerial part fresh mass was also lower in the treatment seven days after inoculation, and root fresh mass was higher for the inoculated control when compared to treatments with ASM. There was no significant difference between treatments in respect of aerial part dry mass and plant height.

ASM is one of the most researched resistance inducers for controlling phytonematodes, and it usually significantly increases plant resistance to the parasite (Owen et al.,
2002; Silva et al., 2002; Chinnasri et al., 2003; Molinari $\&$ Baser, 2010). However, the results of our study were not consistent with these findings, since only Experiment 2 showed difference between application times. ASM was not effective in controlling Meloidogyne exigua Goeldi in coffee cultivar Catuaí 144, and no significant difference was observed between the treatments for final population, number of galls and reproduction factor variables 90 days after inoculation (Salgado et al., 2007). Some authors draw attention to the factors that could cause variations in the results obtained for inducing nematode resistance, that includes dosage, treatment timing, application method and cultivar genetic resistance (Owen et al., 1998; Owen et al., 2002; Molinari \& Baser, 2010).

Irrespective of the cultivar used in this study or the timing of ASM application, the product did not reduce the galls development. This may be due to the time required to induce the plant's resistance mechanisms, since various studies have shown that ASM does not affect hatching, survival and nematode penetration of host roots (Chinnasri et al., 2003; Salgado et al., 2007; Molinari \& Baser, 2010), but it does impair nematode development and reproduction (Chinnasri et al., 2003; Molinari \& Baser, 2010).

The best results for reducing the number of eggs $/ \mathrm{g}$ root were obtained in Experiment 2, irrespective of the cultivar. We also noted that, in this experiment, nematode multiplication was higher than that observed in Experiment 1, perhaps because this was the easiest way of observing the effect of the ASM. Also in Experiment 2, regardless of the cultivar, applying the inducer seven days before inoculation was the treatment that most reduced the

TABLE 2 - Mean values for plant height, aerial part fresh (APFM) and dry (APDM) mass and root fresh mass (RFM) of two soybean cultivars treated with acibenzolar-S-methyl seven days and one day before and seven days after inoculation with 2000 eggs of Meloidogyne javanica in experiments conducted during two different periods

\begin{tabular}{|c|c|c|c|c|c|c|c|c|}
\hline \multirow[t]{2}{*}{ Treatments } & \multicolumn{4}{|c|}{ Experiment 1} & \multicolumn{4}{|c|}{ Experiment 2} \\
\hline & $\begin{array}{c}\text { Height } \\
(\mathrm{cm})\end{array}$ & $\operatorname{APFM}(g)$ & APDM (g) & RFM (g) & $\begin{array}{c}\text { Height } \\
(\mathrm{cm})\end{array}$ & APFM (g) & $\begin{array}{c}\text { APDM } \\
\text { (g) }\end{array}$ & RFM (g) \\
\hline \multicolumn{9}{|c|}{ BRSMT-Pintado (susceptible) } \\
\hline 7 days before & $59.8^{\mathrm{ns}}$ & $9.2^{\mathrm{ns}}$ & $2.6^{\mathrm{ns}}$ & $12.3^{\mathrm{ns}}$ & $60.8 \mathrm{~b}$ & $8.1 \mathrm{~b}$ & $2.3 \mathrm{~b}$ & $15.1 \mathrm{~b}$ \\
\hline 1 day before & 61.6 & 8.9 & 3.0 & 13.6 & $46.2 \mathrm{a}$ & $5.9 \mathrm{ab}$ & $1.6 \mathrm{ab}$ & $9.2 \mathrm{ab}$ \\
\hline 7 days after & 64.6 & 7.6 & 2.2 & 13.1 & $33.8 \mathrm{a}$ & $3.4 \mathrm{a}$ & $0.9 \mathrm{a}$ & $9.0 \mathrm{ab}$ \\
\hline Inoc. Ctrl & 80.8 & 8.7 & 2.7 & 16.4 & $45.2 \mathrm{a}$ & $3.1 \mathrm{a}$ & $0.9 \mathrm{a}$ & $5.7 \mathrm{a}$ \\
\hline Non-inoc Ctrl & 65.3 & 7.3 & 2.1 & 15.1 & $65.4 \mathrm{~b}$ & $6.2 \mathrm{ab}$ & $2.1 \mathrm{~b}$ & $10.6 \mathrm{ab}$ \\
\hline $\mathrm{CV}(\%)$ & 28.5 & 39.4 & 37.1 & 53.5 & 30.5 & 37.0 & 39.6 & 42.1 \\
\hline \multicolumn{9}{|c|}{ MG/BR 46 Conquista (resistant) } \\
\hline 7 days before & $63.8 \mathrm{~b}$ & $8.0 \mathrm{~b}$ & $2.7 \mathrm{~b}$ & $7.5 \mathrm{~b}$ & $65.2^{\text {ns }}$ & $10.3 \mathrm{~b}$ & $3.1^{\mathrm{ns}}$ & $12.9 \mathrm{a}$ \\
\hline 1 day before & $48.2 \mathrm{a}$ & $8.2 \mathrm{~b}$ & $2.6 \mathrm{~b}$ & $7.8 \mathrm{~b}$ & 59.0 & $8.5 \mathrm{ab}$ & 2.5 & $11.8 \mathrm{a}$ \\
\hline 7 days after & $43.3 \mathrm{a}$ & $4.5 \mathrm{a}$ & $1.3 \mathrm{a}$ & $3.0 \mathrm{a}$ & 67.4 & $6.8 \mathrm{a}$ & 2.1 & $11.5 \mathrm{a}$ \\
\hline Inoc. Ctrl & $63.4 \mathrm{~b}$ & $6.4 \mathrm{ab}$ & $1.8 \mathrm{ab}$ & $5.0 \mathrm{ab}$ & 61.2 & $8.9 \mathrm{ab}$ & 2.6 & $20.5 \mathrm{~b}$ \\
\hline Non-inoc Ctrl & $62.0 \mathrm{~b}$ & $8.3 \mathrm{~b}$ & $2.2 \mathrm{ab}$ & $5.9 \mathrm{ab}$ & 65.2 & $11.4 \mathrm{~b}$ & 4.0 & $14.8 \mathrm{ab}$ \\
\hline $\mathrm{CV}(\%)$ & 28.5 & 38.9 & 45.0 & 59.9 & 23.7 & 55.6 & 56.5 & 31.5 \\
\hline
\end{tabular}

For each cultivar, means in columns followed by the same letter did not differ in the Tukey test at $5 \%$ of probability. ${ }^{\text {ns }}=$ not significant. Inoc. Ctrl $=$ Untreated/inoculated control. Non-inoc $\mathrm{Ctrl}=$ Untreated/non-inoculated control. 
nematode population. Similar results were obtained in the treatment of grapevines, in which spraying ASM onto the leaves seven days before inoculation reduced the number of galls and eggs of M. javanica and Meloidogyne arenaria (Neal) Chitwood by 40-80\% (Owen et al., 1998). According to the authors, the plant's defense response was verified by a significant increase in the activity of $\beta-1,3$-glucanases in the roots of ASM-treated plants five days after application of the inducer.

In our experiment, the ASM was evaluated only at the dose recommended by the manufacturer $(0.5 \mathrm{~g} / \mathrm{L})$. However, in some pathosystems, the efficiency of ASM has been boosted by increasing the concentration applied (Chinnarsri et al., 2003; Molinari \& Baser, 2010). In cowpea bean, the reduction in the numbers of Rotylenchulus reniformis Linford \& Oliveira in the root system was proportional when the concentration was increased from 50 to $100 \mathrm{mg} / \mathrm{L}$ water (Chinnasri et al., 2003). In addition to concentration, Molinari \& Baser (2010) evaluated different ASM application methods to control Meloidogyne incognita (Kofoid \& White) Chitwood in tomato and observed that concentrations of 180 and $360 \mathrm{ppm}$ of ASM reduced the reproduction of the nematode when applied directly to the soil. However, when applied to the aerial part, only a much higher dose of ASM (5200 ppm) significantly reduced the number of eggs/g root and parasite reproduction.

In this study the authors were careful in attending the proposed criteria for differentiating the phenomenon of induced resistance from other biological control mechanisms that reduce the severity and incidence of plant diseases (Steiner \& Schönbeck, 1995; Walters et al., 2005; Salgado et al., 2007), especially the elimination of inducerpathogen toxic or competitive effects, which was possible using the spatial separation which involves applying the inducer to the aerial part and protecting the soil into which the nematodes are inoculated (Steiner \& Schönbeck, 1995; Salgado et al., 2007). Temporal separation was also used, and entails applying the inducer before inoculating the pest (nematode) so that the plant has time to activate and express the genes responsible for protecting it (Steiner \& Schönbeck, 1995).

In a soybean crop, Rocha et al. (2000) also failed to observe any significant effects produced by ASM on the population of Heteroderaglycines Ichinohe, but only a tendency towards a drop in the population when ASM was applied by watering into the soil at the highest concentration $(0.3 \mathrm{~g} / \mathrm{L})$. It is possible that in some nematode pathosystems, additional time is required to activate resistance mechanisms. When ASM $(50 \mu$ g i.a. $/ \mathrm{mL})$ was applied to vine leaves, there was no change in the number of Meloidogyne spp. in the roots three days after inoculation, but the population had dropped three weeks after inoculation, a period compatible with plantnematode interaction, when giant cells are induced and maintained in the host, allowing the parasites to feed and grow (Owen et al., 2002). In soybean crop it is impossible to apply the resistance inductor prior to nematode inoculation, since the process occur naturally in areas, even that, the treatment is important because it may reduce feeding sites formed from the second parasite life cycle. However, in the M. incognita-tomato pathosystem, applying ASM three days before or seven days after inoculation resulted in significant reductions in the number of galls, mass of eggs and eggs/g root by comparison with the control (Silva et al., 2002; Silva et al., 2004). The authors have suggested that ASM interferes in the formation of the giant cells by interfering with a protein that is essential to their formation, and therefore affecting nematode reproduction.

For the resistant soybean, cultivar MG/BR 46Conquista, there was no increase in development to the vegetative parameters evaluated by comparison with the untreated/non-inoculated control. Similar results have been reported in pathosystems involving M. javanica and $R$. reniformis-cowpea bean or soybean (Chinnasri et al., 2003), M. incognita-sugarcane (Doihara, 2005); M. exigua-coffee (Salgado et al., 2007) and M. incognita-tomato (Molinari \& Baser, 2010). It is possible that this occurs because the ASM inhibits nematode reproduction, rather than penetration and the induction of feeding sites (Chinnasri et al., 2003; Molinari \& Baser, 2010). On the other hand, in Experiment 2 the susceptible soybean plants treated seven days before inoculation exhibited plant heights, aerial part fresh and dry mass and root fresh mass that were the same or higher than those of the untreated/non-inoculated control.

The study shows that in one of the experiments, applying ASM seven days prior to inoculation was effective in reducing the reproduction of $M$. javanica in soybean, regardless of the susceptibility of the cultivar. However, enhanced plant development was observed only in the susceptible cultivar in Experiment 2. Further studies are thus necessary to assess the efficiency of ASM in the control of $M$. javanica in soybean.

\section{ACKNOWLEDGEMENTS}

The authors would like to thank Coordenação de Aperfeiçoamento de Pessoal de Nível Superior - CAPES (Brazilian Federal Agency for the Support and Evaluation of Graduate Education) for their support, without which this study would not have been possible.

\section{REFERENCES}

Baysal O, Soylu EM, Soylu S (2003) Induction of defence-related enzymes and resistance by the plant activator acibenzolar-S-methyl in tomato seedlings against bacterial canker caused by Clavibacter michiganensis ssp. michiganensis. Plant Pathology 52:747-753.

Benhamou N, Belanger RR (1998) Induction of systemic resistance to Pythium damping-off in cucumber plants by benzothiadiazole: ultrastructure and cytochemistry of the host response. Plant Journal 14:13-21.

Bonaldo SM, Pascholati SF, Romeiro RS (2005) Indução de resistência: noções básicas e perspectivas. In: Cavalcanti LS, Di 
Piero RM, Cia P, Pascholati SF, Resende MLV, Romeiro RS (Eds.) Indução de resistência em plantas a patógenos e insetos. Piracicaba SP. FEALQ. pp. 11-28.

Chinnasri B, Sipes BS, Schmitt DP (2003) Effects of acibenzolarS-methyl application to Rotylenchulus reniformis and Meloidogyne javanica. Journal of Nematology 35:110-114.

Dias-Arieira CR, Marini PM, Fontana LF, Roldi M, Silva TRB (2012) Effect of Azospirillum brasilense, Stimulate ${ }^{\circledR}$ and potassium phosphite to control Pratylenchus brachyurus in soybean and maize. Nematropica 42:170-175.

Doihara PI (2005) Efeito da aplicação de extrato pirolenhoso, óleo de nim (Azadirachta indica) e acibenzolar-S-methyl sobre a interação nematóide-planta hospedeira. MS Dissertation, Universidade Federal Rural de Pernambuco. Recife PE.

Durrant WE, Dong X (2004) Systemic acquired resistance. Annual Review of Phytopathology 42:185-209.

Fabry CFS, Freitas LG, Godinho MM, Neves WS, Ferraz S (2007) Resistência sistêmica a Meloidogyne javanica induzida por Rhizobium etli G12. Nematologia Brasileira 31:5-9.

Franzener G, Martinez-Franzener AS, Stangarlin JR, Furlanetto C, Schwan-Estrada KRF (2007) Proteção de tomateiro a Meloidogyne incognita pelo extrato aquoso de Tagetes patula. Nematologia Brasileira 31:27-36.

Hussey RS, Barker KR (1973) A comparison of methods of collecting inocula of Meloidogyne spp., including a new technique. Plant Disease Reporter 57:1025-1028.

Molinari S, Baser, N (2010) Induction of resistance to root-knot nematodes by SAR elicitors in tomato. Crop Protection 29:13541362 .

Oostendorp M, Kunz W, Dietrisch B, Staub T (2001) Induced disease resistance in plants by chemicals. European Journal of Plant Pathology 107:19-28.

Owen KJ, Green CD, Deverall BJ (1998) Systemic acquired resistance against root-knot nematodes in grapevines. In: $7^{\text {th }}$
International Congress of Plant Pathology, Proceedings... Edinburg UK. International Society for Plant Pathology.

Owen KJ, Green CD, Deverall BJA (2002) Benzothiadiazole applied to foliage reduces development and egg deposition by Meloidogyne spp. in glasshouse-grown grapevine roots. Australasian Plant Pathology 31:47-53.

Rocha MR, Castro RM, Pina RC, Martini AL (2000) Efeito do acibenzolar-S-methyl (benzothiadiazole), como indutor de resistência sistêmica em soja (Glycine $\max \mathrm{cv}$. FT-Cristalina), sobre Heterodera glycines. Pesquisa Agropecuária Tropical 30:3538.

Salgado SML, Resende MLV, Campos VP (2007) Efeito de indutores de resistência sobre Meloidogyne exigua do cafeeiro. Ciência e Agrotecnologia 31:1007-1013.

Silva JFV(2001)Relações parasito-hospedeiro nas meloidogynoses da soja. Londrina PR. Embrapa Soja/Sociedade Brasileira de Nematologia.

Silva LHCP, Campos JR, Campos VP, Dutra MR (2002) Época de aplicação do acibenzolar-S-methyl e da abamectina no controle de Meloidogyne sp. em tomateiro. Fitopatologia Brasileira 27:194.

Silva LHCP, Campos JR, Dutra MR, Campos VP (2004) Aumento da resistência de cultivares de tomate a Meloidogyne incognita com aplicação de acibenzolar-S-methyl. Nematologia Brasileira 28:199-206.

Steiner U, Schönbeck F (1995) Induced resistance to disease in plants. In: Hammerschmialt R, Riyc J (Eds.) Development in Plants Pathology. Dordrecht The Netherlands. Kluwer Academic Pub. pp. 86-110.

Vallad GE, Goodman RM (2004) Systemic acquired resistance and induced systemic resistance in conventional agriculture. Crop Science 44:1920-1934.

Walters DR, Walsh D, Newton AC, Lyon GD (2005) Induced resistance for plant disease control: Maximizing the efficacy of resistance elicitors. Phytopathology 95:1368-1373. 